wealth through education and helps us understand why districts like Detroit are targeted for reform while others remain unchanged. Without attention to this kind of exploitation, the book misses the opportunity to fully interrogate the tensions between democracy and capitalism that underpinned the dismantling of DPS.

These reservations aside, Dismantled is an insightful read for historians of urban education seeking to understand how those promoting market efforts coalesced into a movement powerful enough to shape a state and its largest city's educational system into one of "choice and competition." Equally as important, Kang's work invites historians to think meaningfully about the interplay between state and local government to understand continuities and changes within school systems and how state policies can dismantle one district while fortifying others. For this reason, Dismantled is necessary reading for those contemplating our current educational situation through the past.

doi:10.1017/heq.2021.49

\title{
Kathy Peiss. Information Hunters: When Librarians, Soldiers, and Spies Banded Together in World War II Europe
}

New York: Oxford University Press, 2020. 277 pp.

Molly Guptill Manning (D)

New York Law School

mguptillmanning@gmail.com

Most books about World War II focus on military campaigns, battlefield heroics, and the advances in weaponry and technology that eventually brought an Allied victory. Less understood is how this was a "war of words." Beginning with book burnings in Germany during the 1930s, Nazi Germany kept a tight focus on controlling messages and information: libraries in occupied nations were closed or "reorganized"; archives were hidden, stolen, and/or destroyed; and propaganda leaflets were liberally dumped on civilians and troops across Europe. As precious artifacts and printed materials were lost or destroyed, the need to safeguard and preserve print culture swelled. In Information Hunters, Kathy Peiss provides a fascinating account of how the Library of Congress partnered with the Office of Strategic Services (OSS), a wartime intelligence agency, to acquire publications, archival materials, and records from Germany and the occupied countries of Europe. Meticulously researched and intricately detailed, Information Hunters chronicles this seemingly forgotten chapter of World War II, safeguarding the story, itself, for future generations and historians.

Information Hunters traces the origins of wartime information-gathering and the unlikely coupling of librarianship and spycraft. There was little doubt that the United 
States military was eager to "collect military, technological, economic, political, and psychological information, in order to understand and mobilize against threats to the United States" (p. 19). At the same time, the Library of Congress wished to maintain its usual acquisition of foreign publications-newspapers, academic journals, scientific and technical periodicals, and books. As Germany tightened its grip on the flow of information across Europe, and the war wreaked havoc on international shipping, the interests of the US military and Library of Congress became aligned. Both were eager to get information out of Europe. Thus, they combined forces, sending librarian-agents to Europe where they could subscribe to local periodicals, buy materials from bookstores and newsstands, and microfilm everything and anything they could get their hands on.

At the heart of Peiss's story are the efforts undertaken by individual librarians to undertake "collecting missions" across Europe. Librarians and archivists from leading US universities and cultural institutions were tapped to partake in these missions, lending their expertise and skill in handling and identifying rare books, manuscripts, and the like. One such librarian happened to be Peiss's uncle, Reuben Peiss, who was a librarian at Harvard University when the OSS recruited him to become a field agent in Europe for the acquisition of printed materials (Peiss's prologue explains how she discovered the topic of this book while learning about her uncle's war work). In addition to Reuben Peiss, Information Hunters captures the work and acquisitions of many individuals-women and men-who stealthily purchased and microfilmed materials across Europe.

As V-E Day came and went, the acquisitions work shifted from purchasing materials to the confiscation of massive collections of records and publications. Document centers sprouted up, where materials accumulated to staggering levels. Peiss describes these centers as "archival beehives," where there were "intelligence agents, military groups, government officials, and a bewildering array of civilians swarming over the materials" (p. 101). Although the Allies had a policy of denazification-which prohibited the circulation of Nazi records, documentation, propaganda, and works proselytizing Nazi theories and ideas-the collecting missions worked to accumulate all that they could, recognizing the "great historical import" of such material (p. 114).

Among the artifacts and printed materials discovered by American troops were millions of books and materials that had been looted by the Nazis and then deposited in caves, castles, and other places that were unlikely to be bombed or searched. These looted materials included troves of Jewish religious and cultural objects, which tended to make their way to the Rothschild Library Collecting Point in Frankfurt. The United States' goal was to process these materials and develop a program of book restitution. However, the program was riddled with difficulties and proceeded at a snail's pace. Officials faced a difficult balancing act between restitution for individual owners and "communal restoration" needs, as Jewish scholars and Jewish groups sought access at various collecting points to religious texts and cultural property in the United States' possession.

A number of ethical questions arise over the course of Information Hunters, many of which are difficult to answer given the breadth of the collecting missions and the unique provenance issues that individual items may pose. Was it fair to collect some of the materials, without payment, pursuant to wartime confiscation policies 
(essentially treating publications and records as "war booty")? Did these collecting missions ever cross the line into the realm of illegal takings? Did the mass acquisition of materials for American libraries interfere with the needs for cultural reconstruction in many areas across Europe? In the case of rare books, archival materials, manuscripts, and other materials whose ownership might be traceable (such as through unique bookplates or institutional stamps), were the efforts to reconnect items to their true owners sufficient? To these, and many other ethical questions, Peiss explores the complications in finding clear answers.

One illustrative ethical dilemma detailed in Information Hunters involves the 1946 discovery of Joseph Goebbels's diaries, the Hoover Library's acquisition of them, and Doubleday's deal to publish the diaries in 1948. Peiss capably walks readers through conflicting testimonies of how the diaries were discovered, the circumstances under which they left Germany, and the theories for why the Hoover Library should be the legitimate repository for the diaries and for why Doubleday had permission to publish them. It is a fascinating example that showcases the tangle of bureaucracy, law, international treaties, and ethics that a single work or artifact can present. (In the end, the Alien Property Custodian permitted the diaries to remain in the Hoover Library, but ruled that they had not left Germany through proper channels, and it issued an order in 1949 claiming literary property rights in the published diaries; royalties were siphoned to funds for American prisoners of war and civilian internees.)

Altogether, Kathy Peiss's Information Hunters chronicles an incredibly important slice of World War II history that has largely escaped historical attention. It is a significant contribution to World War II scholarship and a reminder of the preciousness of the written word.

\section{Jonathan Rée, ed., A Schoolmaster's War: Harry Rée, British Agent in the French Resistance}

New Haven, CT: Yale University Press, 2020. 216 pp.

Kathy Peiss (D)

University of Pennsylvania

peiss@sas.upenn.edu

This gem of a book tells the story of Harry Rée, British teacher in peacetime, secret agent during World War II. During his life, Rée wrote and rewrote the saga of his work in the French Resistance, in different genres and for various audiences. A Schoolmaster's War opens to view this clandestine war, its nature, and its ethical complexity. 